\title{
Morphometric study of histological changes in sublabial salivary glands due to aging process
}

\author{
PCM DE WILDE,* JPA BAAK, $†$ JC van HOUWELINGEN, $\ddagger$ L KATER,§ PJ SLOOTWEG*
}

From the *Department of Oral Pathology, University of Utrecht, Utrecht, the Pathological Institute, Free University Hospital, Amsterdam, $\ddagger$ the Department of Mathematical Statistics, University of Utrecht, Utrecht, and the §Division of Immunopathology, Department of Medicine and Institute of Pathology, University Hospital, Utrecht, The Netherlands

SUMMARY The sublabial salivary glands were studied by morphometric methods in 68 healthy volunteers to establish possible changes related to age in those tissue components that are affected in Sjögren's syndrome and connective tissue diseases (and which might simulate Sjögren's syndrome).

There was an increase in the amount of connective tissue and intralobular ducts with age and a corresponding decrease in acinar tissue. During the aging process changes in the intralobular ducts occurred: the outer and inner diameters of these ducts and the thickness of the epithelium decreased, but the ratio of the outer and inner diameters of the ducts remained constant.

The amount of diffuse lymphoplasmacytic infiltrate and the vascularity of the tissue remains constant with age. In 15 of the subjects, however, discrete lymphocytic foci were seen and in six of these more than one focus $/ 4 \mathrm{~mm}^{2}$ of salivary tissue was found, which has been described as suggestive of Sjögren's syndrome. The volume percentage of lymphocytic foci is constant during the aging process.

The histological features commonly used to diagnose Sjögren's syndrome may occur in normal people, and false positive diagnoses will occur if these criteria are rigidly adhered to. Morphometry may provide more reliable criteria for distinguishing changes induced by inflammation and related to age which occur in salivary tissue.

Sublabial salivary gland biopsy is important in the diagnosis of Sjögren's syndrome. ${ }^{1-5}$ The histological changes in minor salivary gland tissue are the same as those in the major salivary glands: acinar atrophy; fibrosis; focal lymphocytic infiltrates; and ductal changes such as hyperplasia and dilatation. The most important diagnostic criterion in Sjögren's syndrome is said to be the "focus score" defined as the number of lymphocytic foci per $4 \mathrm{~mm}^{2}$ of salivary gland tissue. A focus score greater than one is highly suggestive of Sjögren's syndrome. ${ }^{16-9}$ In some connective tissue diseases, however, virtually the same histological changes occur. ${ }^{710-12}$ Indeed, the diagnostic value of the focus score was questioned by Chomette et al, who considered the changes in the intralobular ducts were of greater importance as a diagnostic feature. ${ }^{4}$

Acinar atrophy, fibrosis, and hyperplasia of intra-

Accepted for publication 29 August 1985 lobular ducts as age related changes were first defined morphometrically in the submandibular gland. ${ }^{13-15}$ Focal lymphocytic adenitis in healthy submandibular glands has also been described. ${ }^{16}$

Studies of a limited number of morphometric features in sublabial salivary gland tissue showed that atrophy of acini, fibrosis, and ductal hyperplasia also occur in the minor salivary glands with aging. ${ }^{917}$ Focal lymphocytic adenitis in the sublabial salivary gland tissue of control subjects obtained at necropsy has been described by Scott, ${ }^{17}$ but this is at variance with most authors who describe lymphocytic foci in sublabial salivary gland tissue only in relation to ductal dilatation or in association with Sjögren's syndrome or other connective tissue diseases. ${ }^{16-9}$

As acinar atrophy, fibrosis, and ductal hyperplasia in minor salivary glands are aged related changes they are not suitable as the basis of the histological diagnosis of Sjögren's syndrome. Moreover, the qualitative observations of Scott ${ }^{17}$ of lymphocytic inflammatory activity in normal sublabial salivary gland tissue has 
Table 1 Clinical data

\begin{tabular}{lllll}
\hline $\begin{array}{l}\text { Group } \\
(n=68)\end{array}$ & $\begin{array}{l}\text { Age category } \\
\text { (in years) }\end{array}$ & \multicolumn{2}{l}{$S e x$} & $\begin{array}{c}\text { Mean age } \\
\text { (in years) }\end{array}$ \\
\cline { 2 - 3 } & $M$ & $F$ & \\
\hline I & $10-19$ & 5 & 5 & $16 \cdot 4(2 \cdot 3)$ \\
II & $20-29$ & 9 & 2 & $24 \cdot 0(2 \cdot 8)$ \\
III & $30-39$ & 2 & 5 & $33 \cdot 7(3 \cdot 3)$ \\
IV & $40-49$ & 6 & 4 & $46 \cdot 2(2 \cdot 9)$ \\
V & $50-59$ & 5 & 6 & $54 \cdot 2(3 \cdot 0)$ \\
VI & $60-69$ & 5 & 6 & $63 \cdot 0(2 \cdot 4)$ \\
VII & $70-79$ & 3 & 5 & $75 \cdot 4(2 \cdot 8)$ \\
\hline
\end{tabular}

also made the value of the lymphocytic focus score in the diagnosis of Sjögren's syndrome equivocal. Scott's conclusions are, however, subjective, and a quantitative investigation of the inflammatory phenomena and ductal changes in the sublabial salivary gland tissue of healthy subjects is necessary to obtain reliable baseline data on which distinctions between inflammatory mediated and aging changes can be made.

\section{Material and methods}

Sublabial salivary gland biopsies were obtained with informed consent from 68 patients who had undergone intraoral surgery for cosmetic or preprosthetic purposes. The patients did not suffer from any systemic disease nor had they undergone radiotherapy or chemotherapy before surgery. The subjects were divided into seven age groups. Table 1 summarises their clinical details.

A horizontal incision technique ${ }^{18}$ obtained at least two sublabial salivary glands and the whole yield of glands was examined.

The tissues were fixed in a formol-sublimate solution ${ }^{19}$ and embedded in paraffin. Sections of $5 \mu \mathrm{m}$ were stained with haematoxylin and eosin.

\section{TISSUE COMPONENT DEFINITIONS}

The tissue constituents of morphometric interest were defined as follows:

Acinar tissue: the secretory part of the glandconsisting of serous and mucous acini; the ducts and intralobular connective tissue are not part of the acinar tissue.

Fibrous tissue: the connective tissue within the sublabial salivary gland; the fibrous capsule is excluded. Intralobular ducts (ILD): all ducts within the glandular lobules. Larger ducts in the connective tissue, septa, and hilum of a gland are not included.

Vessels: all vessels situated within the lobules but the larger vessels in the fibrous septa and hilum are excluded.

Lymphocytic focus: an aggregate of more than $50 \mathrm{lym}$ phocytes and histiocytes, usually with a few peripheral plasma cells. ${ }^{20} \mathrm{~A}$ lymphocytic focus has a great den- sity of inflammatory cells and is usually very well demarcated. ${ }^{17}$

Focus score: the number of lymphocytic foci expressed per $4 \mathrm{~mm}^{2}$ of tissue. ${ }^{1}$

Diffuse lymphoplasmacytic infiltrate (DLPI): these consist of the plasma cells and lymphocytes in the fibrous stroma of the gland and areas of fibrosis. A diffuse infiltrate has a low density of cells, mostly plasma cells. All other phenomena of inflammatory activity that did not satisfy the definition of a lymphocytic focus were included in the definition of lymphoplasmacytic infiltrate.

\section{MORPHOMETRIC METHODS}

We used seven indirect or stereological variables and four direct variables to describe the histological changes (Table 2). The equipment used for measurement was a MOP-Videoplan (Kontron, Munich). The outer and inner diameters of intralobular ducts, which had been sectioned tangentially, were measured by recording the smallest value obtained. The indirect variables were determined by point counting directly into a microprocessor. ${ }^{21-23}$

After the counting had been completed the microcomputer calculated the stereological parameters $V_{\mathbf{v}}$ and $\mathrm{J}_{\mathrm{v}}$, as well as the basic statistics. ${ }^{23}$ To measure the volume percentage of acini and fibrous tissue a 42 point multipurpose Weibel test grid system was used $^{21}$; the same grid was also used to determine $\mathbf{J}_{\mathbf{v}}$. For all other indirect parameters a 168 point multipurpose grid was chosen. ${ }^{21}$

The interpoint distance at specimen level is $21.3 \mu \mathrm{m}$ for the M42 grid and $10.67 \mu \mathrm{m}$ for the M168 grid when a $\times 40$ neofluar objective (NA $=0.75)$ is used. Using a $\times 25$ neofluar objective (NA $=0.60$ ) the interpoint distances are $33.3 \mu \mathrm{m}$ and $16.67 \mu \mathrm{m}$ respectively. In all indirect parameters with the exception of $J_{v}$ and volume percentage of foci a $\times \mathbf{4 0}$ objective was used; in $\mathbf{J}_{\mathbf{v}}$ and volume percentage of foci a $\times 25$ objective was used. The direct measurements on the intralobular ducts were performed using a $\times 40$

Table 2 Histological variables studied

\begin{tabular}{ll}
\hline $\begin{array}{l}\text { Direct variables } \\
\text { Diameter }(\mu \mathrm{m})\end{array}$ & $\begin{array}{l}\text { Indirect variables } \\
\text { Volume percentage }\end{array}$ \\
\hline Outer & Acini \\
$\begin{array}{l}\text { Inner } \\
\text { Outer-inner* }\end{array}$ & Fibrous tissue \\
Inner/outer & Intralobular ducts (ILD) \\
& Vessels \\
& Diffuse lymphoplasmacytic infiltrate \\
& (DLPI) \\
& Lymphocytic foci \\
& Length density of intralobular ducts in \\
& mm ${ }^{-2}$
\end{tabular}

*The difference of the outer-inner diameter is a measure of the thickness of the lining epithelium of the intralobular ducts. 
Table 3 Results of the $F$ test on linearity of morphometrical variables

\begin{tabular}{lllll}
\hline Variable & $\begin{array}{l}\text { Biological variation } \\
F\left(v_{1}, v_{2}\right)\end{array}$ & $P$ & $\begin{array}{l}\text { Histological variable } \\
F\left(v_{1}, v_{2}\right)\end{array}$ & $P$ \\
\hline Volume percentage acini & $\mathrm{F}(3,63)=3.98$ & 0.012 & $\mathrm{~F}(3,63)=4.48$ & 0.007 \\
Volume percentage fibrous tissue & $\mathrm{F}(3,63)=3.53$ & 0.019 & $\mathrm{~F}(3,63)=2.70$ & 0.052 \\
Volume percentage vessels & $\mathrm{F}(3,63)=0.50$ & 0.696 & $\mathrm{~F}(3,63)=0.33$ & 0.805 \\
Volume percentage lymphoplasmacytic infiltrate & $\mathrm{F}(3,63)=1.66$ & 0.183 & $\mathrm{~F}(3,63)=1.59$ & 0.199 \\
Volume percentage intralobular ducts & $\mathrm{F}(3,63)=0.61$ & 0.615 & $\mathrm{~F}(3,63)=0.68$ & 0.571 \\
Length density intralobular ducts & $\mathrm{F}(3,63)=4.25$ & 0.008 & $\mathrm{~F}(3,63)=2.91$ & 0.041 \\
Outer diameter & $\mathrm{F}(3,63)=0.83$ & 0.515 & $\mathrm{~F}(3,63)=0.006$ & 0.996 \\
Inner diameter & $\mathrm{F}(3,63)=1.27$ & 0.292 & $\mathrm{~F}(3,63)=0.15$ & 0.926 \\
Outer-inner diameter & $\mathrm{F}(3,63)=1.11$ & 0.352 & $\mathrm{~F}(3,63)=0.20$ & 0.893 \\
Inner/outer diameter & $\mathrm{F}(3,63)=1.49$ & 0.225 & $\mathrm{~F}(3,63)=0.15$ & 0.926 \\
Volume percentage foci & $\mathrm{F}(3,10)=3.76$ & 0.048 & $\mathrm{~F}(3,10)=2.63$ & 0.107 \\
\hline
\end{tabular}

objective. The area of the glands on each specimen was determined with a $\times 4$ objective.

\section{TISSUE SAMPLING}

The test fields were sampled systematically. ${ }^{2124}$ In sublabial salivary gland tissue none of the constituents showed periodicity. The neighbouring fields in horizontal and vertical directions were counted alternately. In cases with much tissue to examine two or more neighbouring test fields were skipped in horizontal and vertical direction. Each test grid covered sublabial salivary gland tissue completely; if this condition was not fulfilled then the test field was not accepted for counting. The first test field chosen was at the periphery of the gland, and the biopsy sampled with 30 to 50 test fields. In practice 1260 to 2100 points were counted to determine the volume percentage of acini and fibrous tissue and 5040 to 8400 points in the



Fig. 1 Fibrosis, acinar atrophy, and ductal hyperplasia with ductal dilatation in a sublabial salivary gland biopsy. (Haematoxylin and eosin.) $\times 60$. measurement of the other volumes. The stereological variables, $V_{v}$ and $J_{v}$, were calculated as the mean value of $V_{v}$ and $J_{v}$ /test field. The standard deviation (SD) was used as a measure of inhomogeneity of the tissue constituents within the sublabial salivary gland tissue, whereas the standard error of mean (SE) was used as a measure for the reproducibility of the results. The standard deviation of the histological variables denoted the biological variation of the histological features. If a tissue component is distributed homogeneously it may be expected that the biological variation in the related histological feature is small.

\section{REPRODUCIBILITY}

A second measurement of the histological variables of a random trial of the subjects in all cases gave results which lay in the $95 \%$ confidence interval of the mean values of the first measurements.

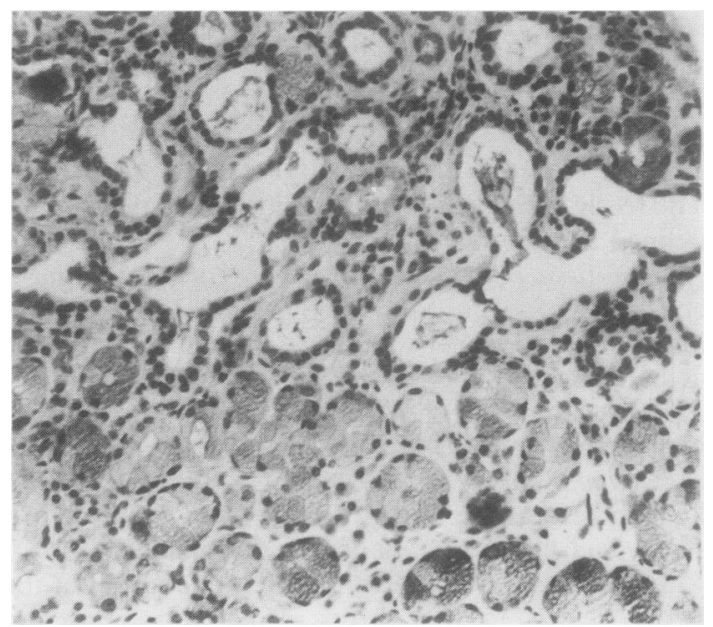

Fig. 2 Area with ductal hyperplasia with dilated ducts and compression of duct lining epithelium cells. In fibrous stroma lymphoplasmacytic infiltrate is present (Haematoxylin and eosin.) $\times 96$. 


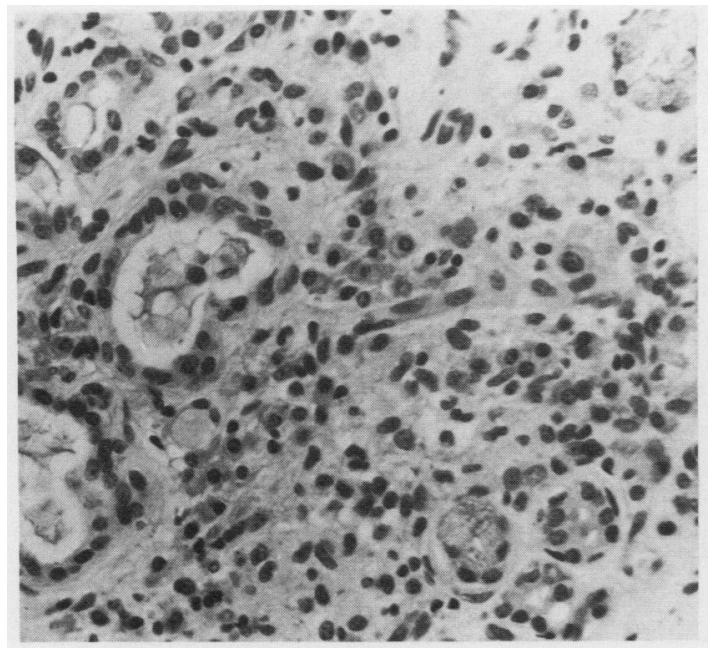

Fig. 3 Detail of lymphoplasmacytic infiltrate characterised by low cell density of lymphocytes and plasma cells (Haematoxylin and eosin.) $\times 240$.

\section{STATISTICAL METHODS}

Investigation of the age dependency of the histological variables and their biological variations by dividing the subjects into age groups gave rise to a loss of information; to avoid this problem polynomial regression analysis of the data was used. The polynomial regression can be described as follows:

$$
y(x)=A+B^{*} x+C^{*} x^{2}+D^{*} x^{3}+E^{*} x^{4}+\ldots
$$

where $\mathrm{y}$ is the dependent variable (histological variable or biological variation) and $\mathrm{x}$ is the dependent

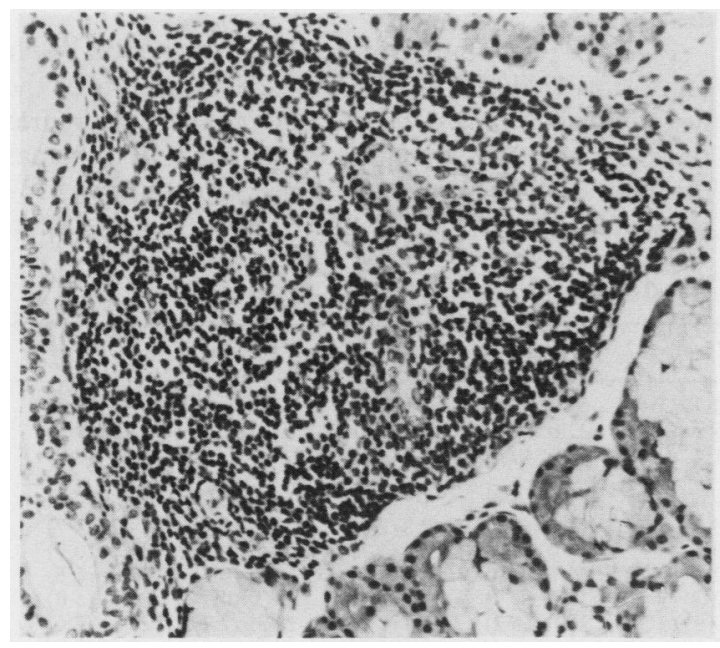

Fig. 4 Large sharply demarcated paraductal lymphocytic focus resulting in locally acinar atrophy. (Haematoxylin and eosin.) $\times 96$. variable (age) of regression. Analysis of the sum of the squared residuals with the $F$ test showed that addition of higher order terms, until degree 4 , does not give a significant improvement of the linear fit at 0.01 significance (Table 3 ). Therefore, a linear regression model $\left(y=A+B^{*} x\right)$ was used to describe the age dependency of the histological variables and the biological variations of these variables. The biological variation was described with an unweighted linear regression model. The histological variables were described with a weighted linear regression model. The results of the linear regression analysis of the biological variations were used as weighting factors. Student's $t$ test was performed to ascertain whether the biological variations and histological variables were significantly dependent on age $\left(\mathrm{H}_{0}: \mathrm{B}=0\right.$ vs $\mathrm{H}_{1}$ : $B \neq 0$ ). Spearman rank correlation analysis was used to investigate the relation between focus score and volume percentage of lymphocytic foci.

Further statistical details can be obtained on request.

\section{Results}

\section{QUALITATIVE DESCRIPTION}

A common change in the sublabial salivary gland is atrophy of acinar tissue with fibrosis (Fig. 1). In areas with fibrosis ductal changes such as ductal hyperplasia and ductal dilatation are seen. (Fig. 1). Ductal dilatation was recognised by increased mean diameter of the ducts and by the compression of the duct lining cells (Figs. 1-2). Ductal hyperplasia was recognised by an increased number of transsected ducts (Fig. 1). Acinar atrophy and ductal changes were often localised.

In all the sublabial salivary gland biopsy specimens plasma cells and a few lymphocytes were present in the stroma of the gland as a diffuse lymphoplasmacytic infiltrate. In areas with fibrosis such an

Table 4 Subjects with one or more lymphocytic foci

\begin{tabular}{llll}
\hline $\begin{array}{l}\text { Age and sex } \\
\text { (years) }\end{array}$ & Foci & & $\begin{array}{l}\text { Mean volume percentage } \\
\text { foci }(S E)\end{array}$ \\
\cline { 2 - 3 } & No & Score & \\
\hline $55 \mathrm{~F}$ & 1 & 0.18 & $0.37(0.37)$ \\
$75 \mathrm{M}$ & 1 & 0.88 & $0.46(0.46)$ \\
$78 \mathrm{~F}$ & 6 & 1.35 & $3.31(1.52)$ \\
$13 \mathrm{M}$ & 2 & 0.60 & $0.94(0.55)$ \\
$12 \mathrm{M}$ & 3 & 0.85 & $0.65(0.51)$ \\
$70 \mathrm{M}$ & 2 & 1.07 & $0.56(0.56)$ \\
$22 \mathrm{M}$ & 2 & 0.44 & $0.42(0.36)$ \\
$24 \mathrm{M}$ & 1 & 0.21 & $0.25(0.25)$ \\
$66 \mathrm{~F}$ & 1 & 0.80 & $0.68(0.68)$ \\
$32 \mathrm{~F}$ & 2 & 1.20 & $1.76(1.20)$ \\
$24 \mathrm{~F}$ & 1 & 0.13 & $0.11(0.11)$ \\
$16 \mathrm{~F}$ & 11 & 1.77 & $1.42(0.51)$ \\
$39 \mathrm{M}$ & 4 & 1.67 & $0.94(0.57)$ \\
$49 \mathrm{~F}$ & 1 & 0.28 & $0.36(0.27)$ \\
$65 \mathrm{~F}$ & 3 & 1.49 & $0.74(0.53)$ \\
\hline
\end{tabular}




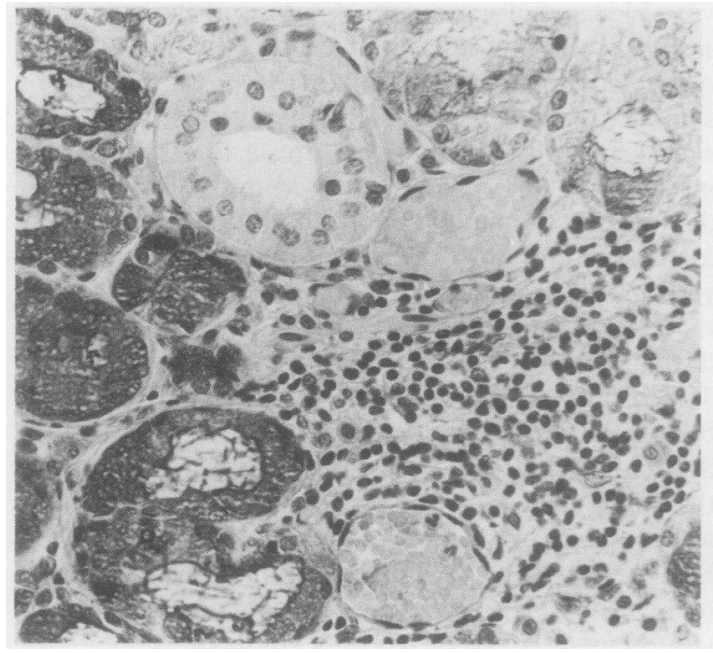

Fig. 5 Lymphocytic focus in surrounding of intralobular ducts and two vessels (Haematoxylin and eosin.) $\times 150$.

infiltrate was nearly always present (Fig. 3). The infiltrates had a low cell density and were not well demarcated. Local aggregates of plasma cells and lymphocytes were common but only in 15 subjects did one or more lymphocytic foci occur. Six of these had a score greater than 1 focus per $4 \mathrm{~mm}^{2}$ salivary tissue. In none of these six subjects followed up for at least two years has there been any indication of a connective tissue disorder. Larger lymphocytic foci can give rise to local parenchymal atrophy (Fig. 4). Foci were observed near blood vessels as paravascular or perivascular and in the neighbourhood of ducts as paraductal or periductal lymphocytic (Figs. 4-6). Confluence of the lymphocytic foci was not seen. Table 4 summarises the details of subjects with lymphocytic foci.

\section{MORPHOMETRY}

Tables 5 and 6 show values of the histological vari-

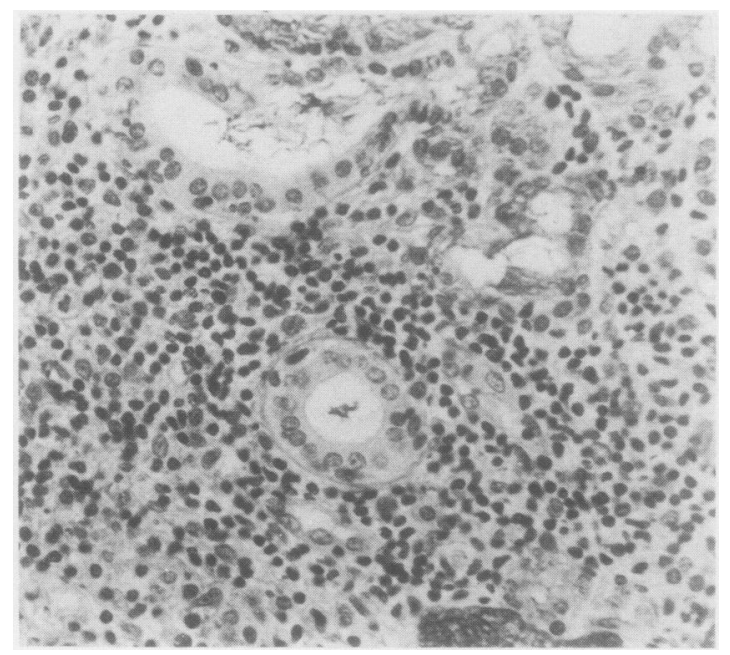

Fig. 6 Periductal lymphocytic focus with local atrophy of acinar tissue (Haematoxylin and eosin.) $\times 150$.

ables and their biological variations within each age group. Analysis of the sum of squared residuals with the $\mathrm{F}$ test showed that higher order terms do not give significant improvement of the linear fit in most morphometrical variables at a level of significance of 0.01 (Table 3). Only the volume percentage of acini and the biological variation of length density of the intralobular ducts could not be described with a linear regression model in a reliable manner. Nevertheless, to obtain some insight in the age dependency factor of the volume percentage of acini and the biological variation of length density the linear regression model was also used.

Figs. $7 \mathrm{a}-\mathrm{j}$ give the results of the unweighted linear regression analysis of the biological variations of the histological variables. The dotted lines in these figures represent the $95 \%$ confidence interval $(\mathrm{CI})$, whereas the uninterrupted symmetrical lines represent the $95 \%$ prediction interval (PI). Table 7 gives the values of $\overline{\mathbf{x}}$,

Table 5 Mean (SD) values of histological variables in graded age groups

\begin{tabular}{|c|c|c|c|c|c|c|c|}
\hline Variable & $I(n=10)$ & $I I(n=I I)$ & $I I I(n=7)$ & $I V(n=10)$ & $V(n=I I)$ & $V I(n=I 1)$ & $V I I(n=8)$ \\
\hline $\begin{array}{l}\text { Volume percentage acini } \\
\text { Volume percentage fibrous tissue } \\
\text { Volume percentage vessels } \\
\text { Volume percentage lymphoplasmacytic } \\
\text { infiltrate } \\
\text { Volume percentage intralobular ducts } \\
\text { Length density intralobular ducts } \\
\text { Outer diameter } \\
\text { Inner diameter } \\
\text { Outer-inner diameter } \\
\text { Inner/outer diameter } \\
\text { Volume percentage foci* }\end{array}$ & $\begin{array}{c}70.0(6.5) \\
20.4(3.9) \\
1.6(0.7) \\
1.2(0.5) \\
3.2(1.3) \\
7.1(4.1) \\
66.7(11.5) \\
34.9(7.9) \\
31.7(4.1) \\
0.50(0.04) \\
1.0(0.39) \\
(n=3)\end{array}$ & $\begin{aligned} & 73.5(6.2) \\
& 18.4(4.6) \\
& 1.6(0.7) \\
& \\
& 1.0(0.5) \\
& 4.1(1.7) \\
& 6.0(3.4) \\
& 69.3(9.9) \\
& 39.2(9.2) \\
& 30.4(4.8) \\
& 0.54(0.06) \\
& 0.26(0.16) \\
&(n=3)\end{aligned}$ & $\begin{array}{cc}70.7 & (3.4) \\
18.2 & (2.6) \\
1.4 & (0.5) \\
& \\
1.0 & (0.5) \\
5.3 & (1.5) \\
9.4 & (6.9) \\
62.4 & (9.2) \\
32.5 & (5.8) \\
29.9(3.5) \\
0.50(0.02) \\
1.4(0.6) \\
(n=2)\end{array}$ & $\begin{aligned} & 66.3(7.8) \\
& 22.0(6.9) \\
& 1.6(0.5) \\
& \\
& 1.0(0.5) \\
& 5.2(2.4) \\
& 10.4(4.4) \\
& 60.1(12.0) \\
& 33.6(7.7) \\
& 26.5(5.2) \\
& 0.53(0.04) \\
& 0.36 \\
&(n=1)\end{aligned}$ & $\begin{array}{c}62 \cdot 0(8 \cdot 8) \\
24 \cdot 8(7 \cdot 5) \\
1 \cdot 6(0 \cdot 6) \\
1 \cdot 1(0 \cdot 3) \\
7 \cdot 3(2 \cdot 1) \\
16 \cdot 7(5 \cdot 7) \\
55 \cdot 5(6 \cdot 5) \\
29 \cdot 4(4 \cdot 1) \\
26 \cdot 1(3 \cdot 9) \\
0 \cdot 52(\cdot 04) \\
0 \cdot 37 \\
(n=1)\end{array}$ & $\begin{array}{c}52.1(17.9) \\
29.1(8.6) \\
1.7(1.1) \\
1.4(0.6) \\
8.2(3.3) \\
19.6(8.3) \\
52.9(6.2) \\
29.7(4.7) \\
24.3(2.7) \\
0.53(0.03) \\
71.0(0.04) \\
(n=2)\end{array}$ & $\begin{array}{c}45.7(14.5) \\
32.8(10.2) \\
2.0(0.7) \\
1.6(0.7) \\
9.7(4.7) \\
30.3(10.9) \\
50.0(6.8) \\
27.7(5.0) \\
22.1(2.6) \\
0.55(0.04) \\
1.4(1.6) \\
(n=3)\end{array}$ \\
\hline
\end{tabular}

*Only the subjects with lymphocytic foci were considered; $n$ is the number of subjects in the age group. 
Table 6 Mean (SD) values of biological variations in graded age groups

\begin{tabular}{|c|c|c|c|c|c|c|c|}
\hline Variable & $I(n=10)$ & $I I(n=I 1)$ & $I I I(n=7)$ & $I V(n=10)$ & $V(n=11)$ & $V I(n=11)$ & $V I I(n=8)$ \\
\hline $\begin{array}{l}\text { Volume percentage acini } \\
\text { Volume percentage fibrous tissue } \\
\text { Volume percentage vessels } \\
\text { Volume percentage lymphoplasmacytic }\end{array}$ & $\begin{array}{l}8.6(2.5) \\
5.8(1.5) \\
1.9(1.1)\end{array}$ & $\begin{array}{l}7.4(2.1) \\
5.5(1.2) \\
1.8 \quad(0.5)\end{array}$ & $\begin{array}{l}8.6(2.1) \\
5.5(1.4) \\
1.5(0.4)\end{array}$ & $\begin{array}{l}9.5(2.9) \\
6.7(1.7) \\
1.8(0.8)\end{array}$ & $\begin{aligned} 11.3 & (3.8) \\
6.9 & (2.5) \\
1.7 & (0.7)\end{aligned}$ & $\begin{array}{r}13.7(6.3) \\
9.6(4.7) \\
1.9(1 \cdot 1)\end{array}$ & $\begin{array}{rr}19.2 & (6.0) \\
13.6 & (5.9) \\
2.1 & (0.9)\end{array}$ \\
\hline $\begin{array}{l}\text { infiltrate } \\
\text { Volume percentage intralobular ducts } \\
\text { Length density intralobular ducts } \\
\text { Outer diameter } \\
\text { Inner diameter } \\
\text { Outer-inner diameter } \\
\text { Inner/outer diameter } \\
\text { Volume percentage foci* }\end{array}$ & $\begin{array}{l}1 \cdot 3(0 \cdot 4) \\
5 \cdot 8(1 \cdot 7) \\
14 \cdot 2(6 \cdot 5) \\
18.9(4 \cdot 7) \\
14 \cdot 5(4 \cdot 1) \\
7 \cdot 0(2 \cdot 8) \\
0 \cdot 10(0 \cdot 03) \\
4 \cdot 5(0 \cdot 6) \\
(n=3)\end{array}$ & $\begin{array}{l}1.0(0.4) \\
6 \cdot 5(2 \cdot 6) \\
13.6(4 \cdot 3) \\
21 \cdot 3(10 \cdot 0) \\
17.8(9 \cdot 7) \\
7.8(1 \cdot 8) \\
0.11(0 \cdot 04) \\
2 \cdot 1(1 \cdot 0) \\
(\mathrm{n}=3)\end{array}$ & $\begin{array}{l}1.0(0 \cdot 3) \\
7 \cdot 3(1 \cdot 4) \\
16 \cdot 2(7 \cdot 7) \\
20 \cdot 4(5 \cdot 6) \\
15 \cdot 7(5 \cdot 5) \\
8 \cdot 6(2 \cdot 0) \\
0 \cdot 11(0.04) \\
6 \cdot 8(1 \cdot 8) \\
(n=2)\end{array}$ & $\begin{array}{l}1 \cdot 0(0 \cdot 4) \\
6 \cdot 7(2 \cdot 1) \\
19 \cdot 9(6 \cdot 1) \\
21 \cdot 7(8 \cdot 5) \\
17.9(6 \cdot 5) \\
7 \cdot 3(1 \cdot 6) \\
0 \cdot 12(0 \cdot 02) \\
2 \cdot 5 \\
(\mathrm{n}=1)\end{array}$ & $\begin{array}{l}1 \cdot 0(0 \cdot 3) \\
8 \cdot 1(2 \cdot 2) \\
26 \cdot 2(6 \cdot 1) \\
16 \cdot 2(5 \cdot 1) \\
12 \cdot 5(4 \cdot 9) \\
7 \cdot 1(1 \cdot 1) \\
0 \cdot 11(0 \cdot 02) \\
3 \cdot 7 \\
(\mathrm{n}=1)\end{array}$ & $\begin{array}{l}1 \cdot 2(0 \cdot 4) \\
8 \cdot 4(1 \cdot 6) \\
27 \cdot 6(7 \cdot 0) \\
15 \cdot 2(4 \cdot 5) \\
12.8(3 \cdot 2) \\
6 \cdot 3(1 \cdot 5) \\
0 \cdot 11(0 \cdot 02) \\
3 \cdot 7(0 \cdot 4) \\
(n=2)\end{array}$ & $\begin{array}{l}1 \cdot 3(0 \cdot 4) \\
9.9(3 \cdot 1) \\
40 \cdot 0(11 \cdot 8) \\
14 \cdot 7(6 \cdot 5) \\
11 \cdot 6(6 \cdot 1) \\
5 \cdot 9(2 \cdot 0) \\
0 \cdot 11(0 \cdot 02) \\
6 \cdot 7(4 \cdot 0) \\
(n=3)\end{array}$ \\
\hline
\end{tabular}

*Only subjects with lymphocytic foci were considered; $n$ is the number of subjects in the age group.

$\bar{y}, s_{\bar{y}}, B$ and $s_{B}$, which characterise the regression lines, as well as the two tailed $\mathrm{p}$ values obtained from the $t$ test of age dependency of the biological variations.

At a confidence level of 0.01 the biological variations of the volume percentage of acini, fibrous tissue, and intralobular ducts increase significantly with age. It was evident that despite the non-linearity of the biological variation of length density this variable also increased with age. At 0.01 level of significance the biological variation of the volume percentage of vessels, volume percentage of lymphoplasmacytic infiltrate, outer, inner, outer-inner, and inner/outer diameters was constant during the aging process. In the group of subjects with lymphocytic foci the biological variation of the volume percentage of foci was also constant during aging.

Figs $8 \mathrm{a}-\mathrm{j}$ show the regression lines, as well as the $95 \%$ confidence interval of the mean values and $95 \%$ prediction interval of the histological variables. The most obvious consequence of applying the weighted regression model was the convergence or divergence of the $95 \%$ prediction interval.

Table 8 gives the values of $\bar{x}, \bar{y}, s_{\bar{y}}, B$ and $s_{B}$. The two tailed $\mathrm{p}$ values obtained from the $t$ test on the age dependency of the histological variables are also given in Table 8.

The aging process was accompanied by atrophy of acini and fibrosis represented by a decrease of the volume percentage of acini and an increase of the volume percentage of fibrous tissue. The volume percentage of the intralobular ducts and length density of intralobular ducts increased with age, whereas the outer diameter, inner diameter, and the thickness of the intralobular duct epithelium decreased, the ratio of inner and outer diameters remained constant during aging. The volume percentage of vessels and lymphoplasmacytic infiltrate were also constant during aging. In the subgroup of 15 subjects with lymphocytic foci the volume percentage of foci remained constant during aging. Figs. $9 \mathrm{a}$ and $\mathrm{b}$ show the regression lines, $95 \%$ confidence interval, and $95 \%$ prediction interval of the volume percentage of lymphocytic foci and its biological variation. In this subgroup there was a highly significant correlation between the focus score and the volume percentage of foci. The Spearman rank correlation coefficient was calculated as $\rho=$ $0.829(p<0.001)$.

Table 7 Results of unweighted regression analysis of biological variations

\begin{tabular}{|c|c|c|c|c|c|c|}
\hline Biological variation of variable & $\overline{\boldsymbol{x}}$ & $\bar{y}\left(s_{5}\right)$ & $B\left(\mathrm{~s}_{\mathrm{B}}\right)$ & & $\begin{array}{l}\text { Two tailed p } \\
\text { value }\end{array}$ & Conclusion \\
\hline $\begin{array}{l}\text { Volume percentage acini } \\
\text { Volume percentage fibrous tissue } \\
\text { Volume percentage vessels } \\
\text { Volume percentage lymphoplasmacytic } \\
\text { infiltrate } \\
\text { Volume percentage intralobular ducts } \\
\text { Length density intralobular ducts } \\
\text { Outer diameter } \\
\text { Inner diameter } \\
\text { Outer-inner diameter } \\
\text { Inner/outer diameter } \\
\text { Volume percentage foci* }\end{array}$ & $\begin{array}{l}44 \cdot 38 \\
44 \cdot 38 \\
44 \cdot 38 \\
44 \cdot 38 \\
44 \cdot 38 \\
44 \cdot 38 \\
44 \cdot 38 \\
44 \cdot 38 \\
44 \cdot 38 \\
44 \cdot 38 \\
42 \cdot 77\end{array}$ & $\begin{aligned} & 11.03(0.50) \\
& 7.58(0.40) \\
& 1.81(0.10) \\
& \\
& 1.11(0.04) \\
& 7.48(0.26) \\
& 22.28(0.87) \\
& 18.35(0.82) \\
& 14.69(0.74) \\
& 7.10(0.23) \\
& 0.107(0.003) \\
& 4.47(0.63)\end{aligned}$ & $\begin{array}{l}0.17 \\
0.11 \\
0.0027 \\
\\
0.00077 \\
0.06 \\
0.41 \\
-0.11 \\
-0.08 \\
-0.03 \\
0.00013 \\
0.03\end{array}$ & $\begin{array}{l}(0.03) \\
(0.02) \\
(0.005) \\
(0.0022) \\
(0.01) \\
(0.04) \\
(0.04) \\
(0.04) \\
(0.01) \\
(0.00016) \\
(0.03)\end{array}$ & $\left.\begin{array}{r}<0.001 \\
<0.001 \\
0.60 \\
0.73 \\
<0.001 \\
<0.001 \\
0.01 \\
0.05 \\
0.02 \\
0.42 \\
0.24\end{array}\right\}$ & $\begin{array}{l}\text { Increases with increasing age } \\
\text { Constant during aging pro- } \\
\text { cess } \\
\text { Increases with increasing age } \\
\text { Constant during aging pro- } \\
\text { cess } \\
\text { Constant during aging pro- } \\
\text { cess } \\
\text { Constant during aging pro- } \\
\text { cess }\end{array}$ \\
\hline
\end{tabular}

*Only the subjects with lymphocytic foci were included. 

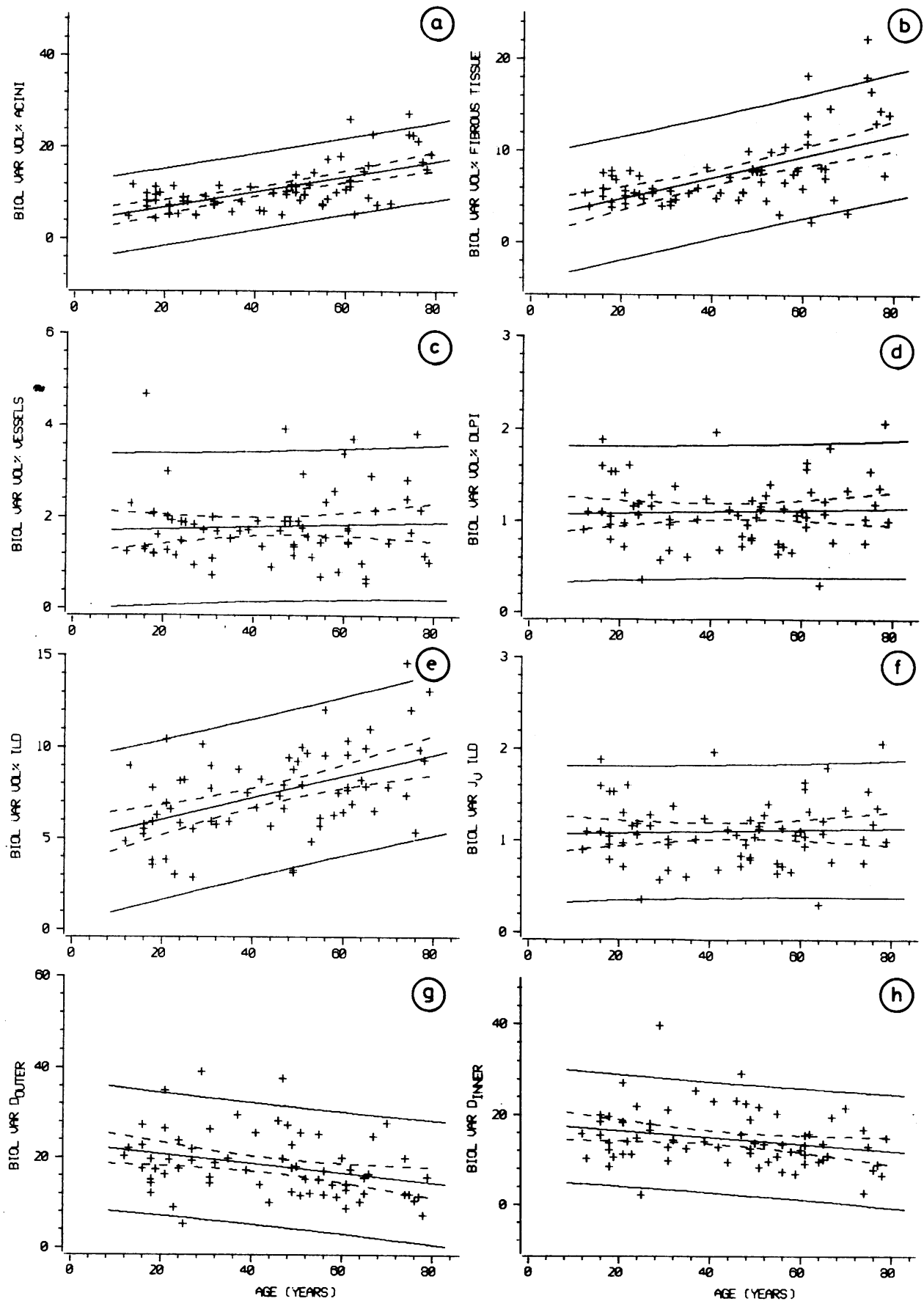

Figs. $7 \mathrm{a}-\mathrm{j}$ Regression lines of biological variations of the histological variables and their $95 \%$ confidence interval and $95 \%$ prediction interval. 


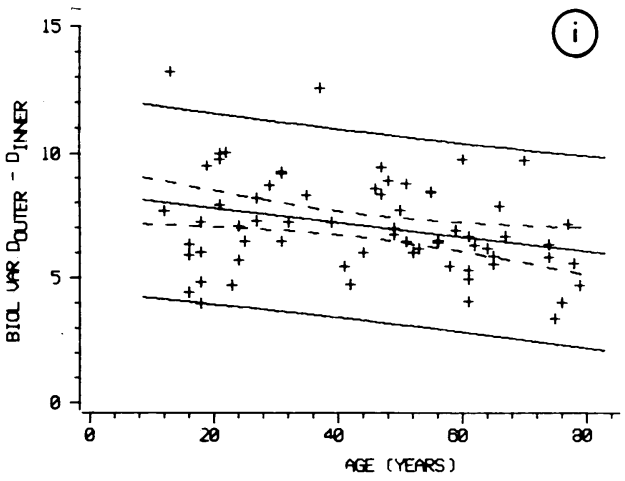

Fig. 7 (continued)

\section{Discussion}

We found a considerable reduction of acinous tissue and an increase of fibrous tissue with increasing age in the salivary glands, and these results agree with other quantitative studies. ${ }^{917}$ Our finding of a constant volume percentage of vessels in aging also agrees with the morphometrical observations of Drummond and Chisholm. ${ }^{9}$

A lymphoplasmacytic infiltrate in sublabial salivary gland tissue has been observed by several investigators. ${ }^{16-9172526}$ Syrjänen and Syrjänen found a volume percentage of lymphoplasmacytic infiltrate of $2.9(\mathrm{SD}=1.6)$ in a morphometrical study of 29 healthy adults, (aged between 19 and 49 years). ${ }^{26}$ Our results from the age groups II, III, and IV combined, found a volume percentage of lymphoplasmacytic infiltrate of $1.0(S D=0.5)$. Scott reported that the prevalence of lymphoplasmacytic infiltrate was unrelated to age ${ }^{17}$ and this is in keeping with our quantitative study. In contrast with this, however, Drummond and Chisholm found that the diffuse infiltrates of lymphocytes were more common

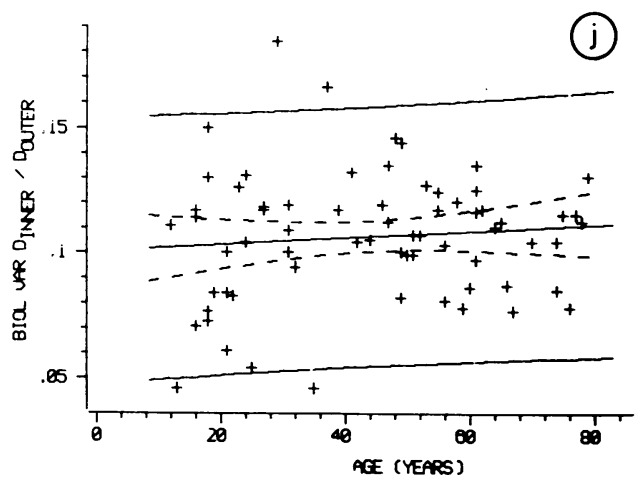

in older glands. ${ }^{9}$ An appreciable increase of the volume percentage of ducts in sublabial salivary gland tissue with advancing age agrees with other morphometrically obtained results. ${ }^{917}$

The increase in volume percentage of ducts may be due to dilatation or an increase in number of ducts. Drummond and Chisholm stated that the increase in volume in sublabial salivary gland is a reflection of mild duct dilatation but also is partly a result of ductal hyperplasia. ${ }^{9}$ Our findings that the inner and outer duct diameters decrease with age imply that the relative increase of the volume of duct component cannot be attributed to ductal dilatation but rather to an increased number of ducts. This conclusion is supported by our observation that there is also an increase in the length density of intralobular ducts during the aging process. It is impossible to draw firm conclusions about real ductal hyperplasia, because all stereological variables such as length density and volume density are relative magnitudes only. Quantitative studies on the changes in the total volume of the sublabial glands as a consequence of aging have not been performed as far as we know.

Table 8 Results of weighted regression analysis of histological variables

\begin{tabular}{|c|c|c|c|c|c|}
\hline Histological variable & $\bar{x}$ & $\bar{y}\left(s_{\bar{y}}\right)$ & $B\left(\mathbf{s}_{\mathbf{B}}\right)$ & $\begin{array}{l}\text { Two tailed p } \\
\text { value }\end{array}$ & Conclusion \\
\hline $\begin{array}{l}\text { Volume percentage acini } \\
\text { Volume percentage fibrous tissue } \\
\text { Volume percentage vessels } \\
\text { Volume percentage lymphoplasmacytic } \\
\text { infiltrate } \\
\text { Volume percentage intralobular ducts } \\
\text { Length density intralobular ducts } \\
\text { Outer diameter } \\
\text { Inner diameter } \\
\text { Outer - inner diameter } \\
\text { Inner/outer diameter } \\
\text { Volume percentage foci* }\end{array}$ & $\begin{array}{l}43 \cdot 84 \\
40 \cdot 98 \\
28 \cdot 99 \\
48 \cdot 84 \\
48 \cdot 46 \\
47 \cdot 45 \\
43 \cdot 03 \\
\\
34.95\end{array}$ & $\begin{array}{c}1 \cdot 16(0.06) \\
5 \cdot 75(0.29) \\
9.18(0.63) \\
58 \cdot 17(1.02) \\
31.91(0.77) \\
26.78(0.45) \\
0.525(0.005) \\
0.82(0.18)\end{array}$ & $\begin{array}{c}0.0068(0.0032) \\
0.10(0.02) \\
0.29(0.04) \\
-0.34(0.06) \\
-0.17(0.04) \\
-0.16(0.03) \\
0.00035(0.00026)\end{array}$ & $\left.\begin{array}{r}0.04 \\
<0.001 \\
<0.001 \\
<0.001 \\
<0.001 \\
<0.001 \\
0.17\end{array}\right\}$ & $\begin{array}{l}\text { Decreases with increasing age } \\
\text { Increases with increasing age } \\
\text { Constant during aging pro- } \\
\text { cess } \\
\text { Increases with increasing age } \\
\text { Decreases with increasing age } \\
\text { Constant during aging pro- } \\
\text { cess }\end{array}$ \\
\hline
\end{tabular}

*Only the subjects with lymphocytic foci were included. 
(a)
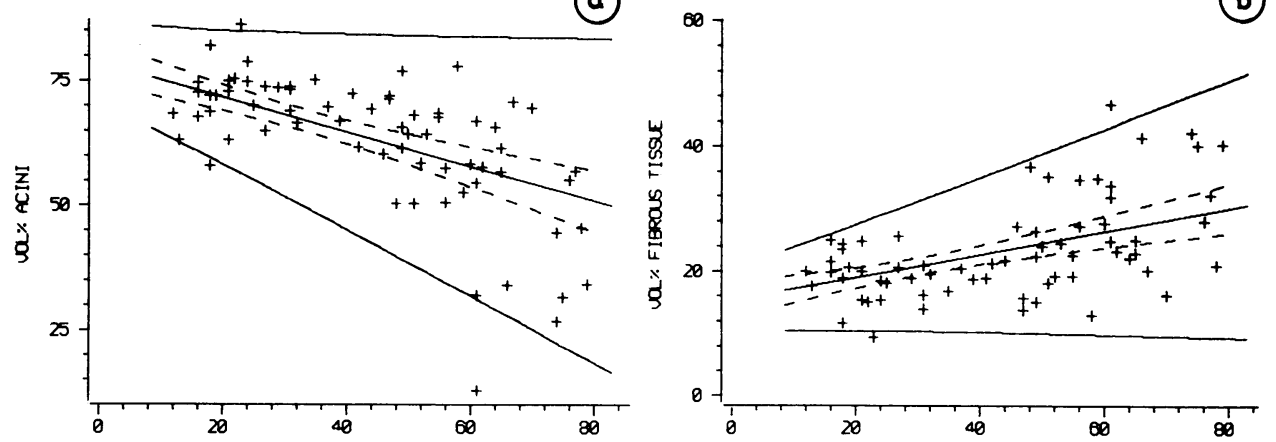

(b)
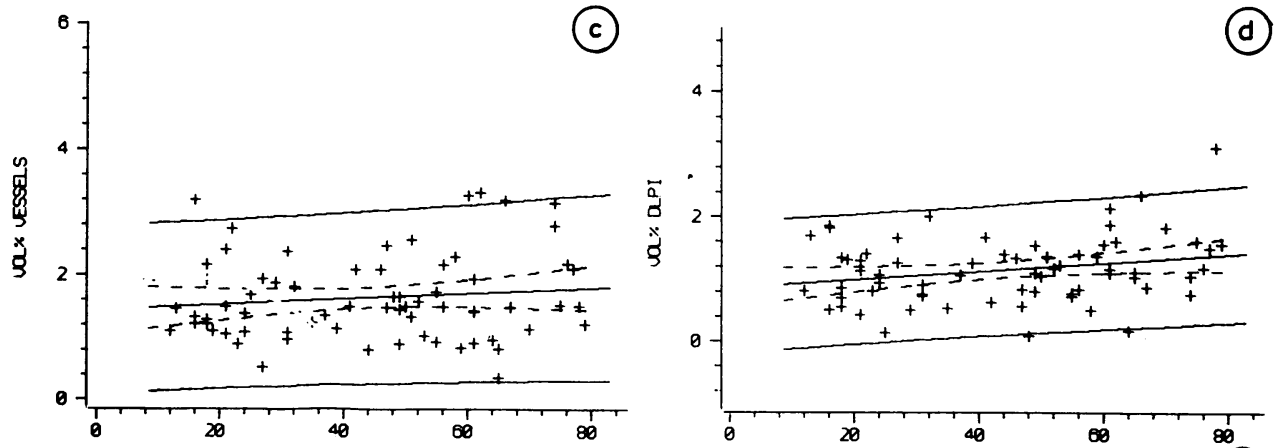

(d)
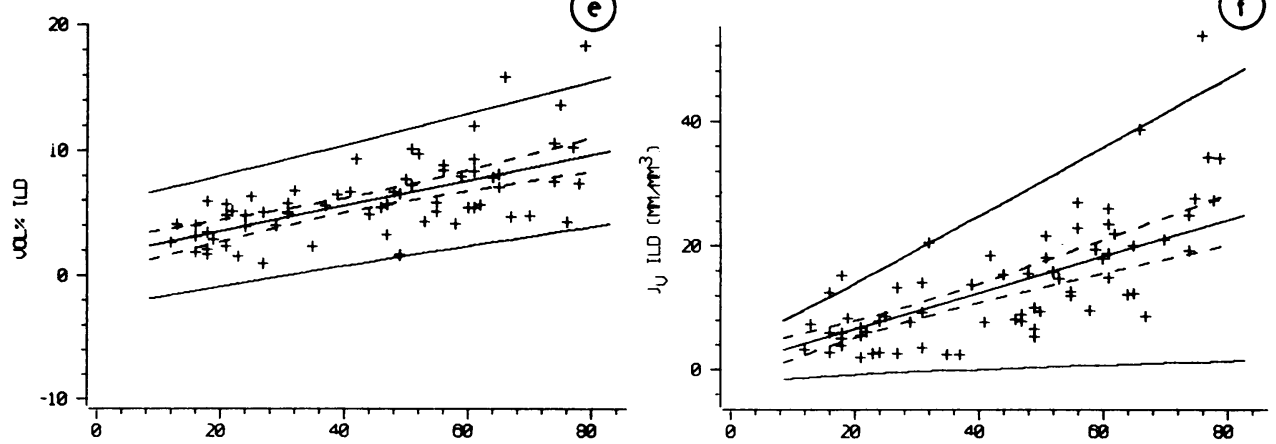

(f)
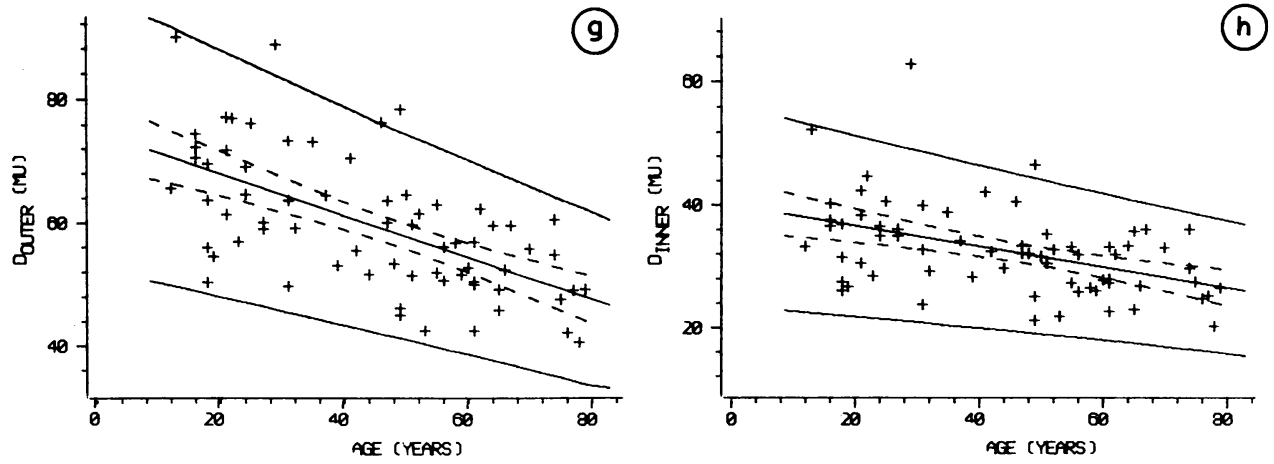

(h)

Figs. 8a-j Regression lines of histological variables and their $95 \%$ confidence interval and $95 \%$ prediction interval. 


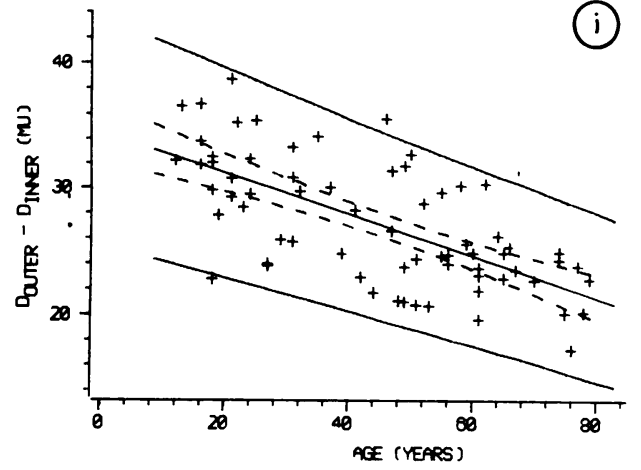

Fig. 8 (continued)

Our study shows that the outer minus inner diameter which is a measure of the thickness of the intralobular duct epithelium, decrease with advancing age, while the ratio of inner and outer diameter is constant during aging. Ductal dilatation, qualitatively recognised by increased mean diameter and the compression of the duct lining cells, ${ }^{17}$ can only be considered as a local feature. Generally, the morphometric manifestations of the age dependent ductal changes can be described as: an increase of the volume percentage of intralobular ducts, as a consequence of a strong increase of the length density of intralobular ducts in combination with a decrease of the inner and outer diameter of intralobular ducts, and a compression of the intralobular ducts lining epithelium.

Quantitatively obtained data of the ductal proportions have not been clearly documented. Table 9 summarises the quantitative results of several authors who studied somewhat comparable age groups. Differences in origin of the material, fixatives, exact age ranges, and distribution of subjects within the age

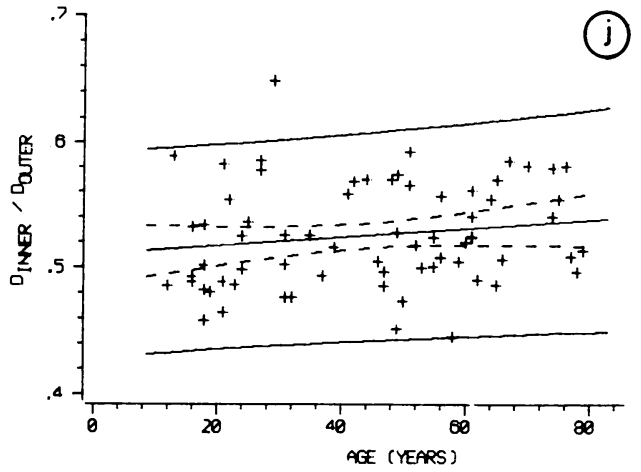

range, definitions of the investigated tissue constituents, and differences in methods of measuring and sampling, however, make it impossible to make exact comparisons with our figures (Table 9).

Lymphocytic foci, which are considered to be very important in the diagnosis of Sjögren's syndrome, were observed in $22 \%$ of the subjects, and nearly $9 \%$ of the investigated subjects had a focus score greater than one per $4 \mathrm{~mm}^{2}$ of sublabial salivary gland tissue.

The presence of lymphocytic foci in healthy sublabial salivary gland tissue has also been described by other investigators, ${ }^{1727}$ but they gave no quantitative information. The lymphocytic foci of healthy minor salivary glands of the palatal mucosa have also been described. ${ }^{28}$ Most studies concerning sublabial salivary gland biopsies do not mention lymphocytic foci. ${ }^{156891825}$ The diagnostic value of sublabial salivary gland biopsy is controversial. Mach et al thought that a biopsy of the sublabial salivary gland does not provide specific information, ${ }^{29}$ but Daniels stated that focal lymphocytic foci in an adequate sub-
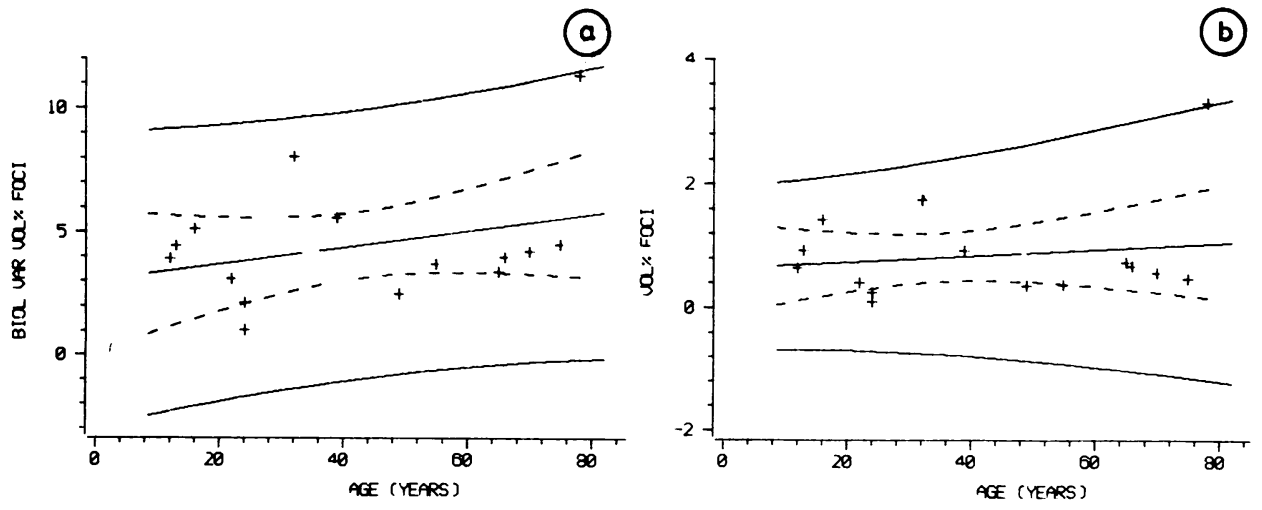

Figs. 9a and b Regression lines of volume percentage foci and its biological variation of subgroup of 15 subjects with lymphocytic foci. 
Table 9 Comparisons with other morphometrical studies on sublabial salivary gland tissue

\begin{tabular}{|c|c|c|c|c|c|c|c|c|}
\hline Source & $\begin{array}{l}\text { Mean }(S D) \\
\text { volume percentage } \\
\text { acini }\end{array}$ & $\begin{array}{l}\text { Mean (SD) } \\
\text { volume percentage } \\
\text { fibrous tissue }\end{array}$ & $\begin{array}{l}\text { Mean }(S D) \\
\text { volume percentage } \\
\text { ducts }\end{array}$ & $\begin{array}{l}\text { Mean }(S D) \\
\text { volume percentage } \\
\text { vessels }\end{array}$ & $N$ & Origin & $\begin{array}{l}\text { Age range } \\
\text { (years) }\end{array}$ & Fixative \\
\hline $\begin{array}{c}26 \\
17 \\
9 \\
\text { De Wilde et al }\end{array}$ & $\begin{array}{l}63 \cdot 5(5 \cdot 4) \\
56 \cdot 7(7 \cdot 9) \\
56 \cdot 1(8 \cdot 3) \\
70 \cdot 1(6 \cdot 6)\end{array}$ & $\begin{array}{l}19 \cdot 0(3 \cdot 6) \\
29 \cdot 8(9 \cdot 7) \\
19 \cdot 8(3 \cdot 4)\end{array}$ & $\begin{array}{l}8.9(2.9) * \\
8.5(3.9) \dagger \\
9.2(2.1) \dagger \dagger \\
4.4(1.8) \$\end{array}$ & $\begin{array}{l}3.7(1 \cdot 2)^{*} \\
3.5(1 \cdot 0) \dagger \dagger \\
1.6(0.6) \$\end{array}$ & $\begin{array}{l}29 \\
20 \\
12 \\
28\end{array}$ & $\begin{array}{l}\text { volunteers } \\
\text { necropsy } \\
\text { necropsy } \\
\text { volunteers }\end{array}$ & $\begin{array}{l}19-49 \\
18-40 \\
25-44 \\
20-49\end{array}$ & $\begin{array}{l}10 \% \text { neutral fo } \\
10 \% \text { formol } \\
\text { unknown } \\
\text { sublimate-formo }\end{array}$ \\
\hline
\end{tabular}

*striated and intercalated ducts and all vessels; fall ducts; łall ducts and all vessels; §intralobular ducts and intralobular vessels.

labial salivary gland biopsy is an objective feature that is more specific of Sjögren's syndrome than xerostomia, or other feature of salivary gland disease. ${ }^{5}$

Most authors consider a lymphoid focus score greater than 1 as the most important diagnostic criterion for Sjögren's syndrome. ${ }^{12530-33}$ Chomette et $a l$, however, asserted that the pathological changes of the intralobular ducts were of greater importance in the diagnosis of Sjögren's syndrome than the presence of lymphoid foci. ${ }^{4}$

From our quantitative study of 68 sublabial salivary gland biopsies of healthy subjects it seems that lymphocytic foci, even with a focus score greater than 1 focus $/ 4 \mathrm{~mm}^{2}$ are not pathognomonic for Sjögren's syndrome and that application of this criterion results in false positive diagnoses. The age dependent changes in the intralobular component also make the conclusions of Chomette $e t \mathrm{al}^{4}$ concerning the diagnostic value of the changes in intralobular ducts of doubtful value.

From this study we conclude that the histological changes in the sublabial salivary gland tissue widely believed to be characteristic for Sjögren's syndrome such as acinar atrophy, focal lymphocytic adenitis, fibrosis, ductal dilatation, and ductal hyperplasia can also be observed in sublabial salivary gland tissue of subjects who are not suffering from any systemic disorder, and can partly be ascribed to the aging process. Although these phenomena may also occur in Sjögren's syndrome they are certainly not pathognomonic for it, and if pathologists place undue reliance on such criteria then false positive diagnoses of Sjögren's syndrome will occur.

Furthermore, the age dependent inhomogeneity of minor salivary gland tissue constituents, which has important consequences for the reference values of the histological variables, has not been investigated before. In the assessment of acinar atrophy, fibrosis, ductal dilatation, and ductal hyperplasia in the sublabial salivary gland tissue it is necessary to bear in mind that the divergence or convergence of the $95 \%$ prediction interval of most histological variables gives rise to ranges of reference values that can vary strongly with age.

Similar features occur in the salivary glands due to aging and as a result of Sjögren's syndrome. Separation of these processes cannot be made by simple qualitative examination of tissue. Detailed morphometry, however, may provide a means of separating these entities by a more reliable set of diagnostic features. Such a morphometric study is currently being undertaken.

Full details of the statistical handling of the results may be obtained from the authors.

This study was financially supported by the Utrecht Foundation For The Benefit of Maxillo-Facial Surgery.

We thank the staff members and residents of the department of maxillo-facial surgery of the University Hospital Utrecht for their cooperation.

\section{References}

${ }^{1}$ Chisholm DM, Mason DK. Labial salivary gland biopsy in Sjögren's disease. J Clin Pathol 1968;21:656-60.

${ }^{2}$ Tarpley TM, Anderson LG, White CL. Minor salivary gland involvement in Sjögren's Syndrome. Oral Surg 1974;37:64-74.

${ }^{3}$ Daniels TE, Silverman S, Michalski JP, Greenspan JS, Sylvester RA, Talal N. The oral component of Sjögren's syndrome. Oral Surg 1975;39:875-85.

${ }^{4}$ Chomette G, Auriol M, van Cat N, Szpirglas H, Tranbaloc P, Vaillant JM. Biopsie des glandes salivaires labiales dans le syndrome de Gougerot-Sjögren. Virchows Arch (Pathol Anat) 1981;392:339-54.

${ }^{5}$ Daniels TE. Labial salivary gland biopsy in Sjögren's syndrome. Arthritis Rheum 1984;27:147-56.

${ }^{6}$ Chisholm DM, Waterhouse JP, Mason DK. Lymphocytic sialadenitis in the major and minor glands: a correlation in postmortem subjects. J Clin Pathol 1970;23:690-4.

${ }^{7}$ Davies JD, Berry H, Bacon PA, Issa MA, Schofield JJ. Labial sialadenitis in Sjögren's syndrome and rheumatoid arthritis. $J$ Pathol 1973;109:307-14.

${ }^{8}$ Friedman H, Kilmar V, Galletta VP, Cossermelli W. Lip biopsy in connective tissue diseases. A review and study of seventy cases. Oral Surg 1979;47:256-62.

${ }^{9}$ Drummond JR, Chisholm DM. A qualitative and quantitative study of the ageing human salivary glands. Arch Oral Biol 1984;29:151-5.

${ }^{10}$ Alarcon-Segóvia D, Ibánez G, Hernández-Ortiz J, VelázquezForero F, González-Jiménez Y. Sjögren's syndrome in progressive systemic sclerosis (scleroderma). Am J Med 1974;57:78-85.

${ }^{11}$ Cipoletti JF, Buckingham RB, Barnes EL, et al. Sjögren's syndrome in progressive systemic sclerosis. Ann Intern Med 
1977;87:535-41.

${ }^{12}$ Kazandjian S, Fiessinger JN, Mignot J, Vayssairat M, Camilleri JP, Housset E. Quantification de la sclérose des glandes salivaires labiales au cours de la sclérodermie généralisée. Nouv Presse Méd 1981:10:317-23.

${ }^{13}$ Waterhouse JP, Chisholm DM, Winter RB, Patel M, Yale RS. Replacement of functional parenchymal cells by fat and connective tissue in human submandibular glands: an age-related change. J Oral Pathol 1973;2:16-27.

${ }^{14} \mathrm{Scott} \mathrm{J}$. A morphometric study of age changes in the histology of the ducts of human submandibular salivary glands. Arch Oral Biol 1977a;22:243-9.

${ }^{15}$ Scott J. Degenerative changes in the histology of the human submandibular salivary gland occurring with age. J Biol Bucc 1977b;5:311-9.

${ }^{16} \mathrm{Scott} \mathrm{J}$. The incidence of focal chronic inflammatory changes in human submandibular salivary glands. $J$ Oral Pathol 1976;5:334-6.

${ }^{17}$ Scott J. Qualitative and quantitative observations on the histology of human labial salivary glands obtained post mortem. J Biol Bucc 1980;8:187-200.

${ }^{18}$ Greenspan JS, Daniels TE, Talal N, Sylvester RA. The histopathology of Sjögren's syndrome in labial salivary gland biopsies. Oral Surg 1974;37:217-29.

${ }^{19}$ Bosman FT, Lindeman J, Kuiper G, Van Der Wal A, Kreunig J. The influence of fixation on immunoperoxidase staining of plasma cells in paraffin sections of intestinal biopsy specimens. Histochemistry 1977;53:57-62.

${ }^{20}$ Waterhouse JP, Doniach I. Post-mortem prevalence of focal lymphocytic adenitis of the submandibular salivary gland. $J$ Pathol Bacteriol 1966;91:53-64.

${ }^{21}$ Weibel ER. Stereological methods. Vol 1. Practical methods for biological morphometry. London: Academic Press, 1979.

22 Baak JPA, Oort J. A manual of morphometry in diagnostic pathology. Berlin: Springer Verlag, 1983.

${ }^{23} \mathrm{Knol}$ RGF, De Wilde PCM, Slootweg PJ. A BASIC program for computer assisted point counting technique. (in press).

${ }^{24}$ Cochran WG. Sampling techniques 3rd ed. New York: John Wiley and Sons, 1977.

${ }^{25}$ Fiessinger JN, Camilleri JP, Amat C, Ollier MP, Housset E, Hartman L. Salivary immunoglobulins in progressive systemic sclerosis. Biomedicine 1978;28:298-303.

${ }^{26}$ Syrjänen SM, Syrjänen KJ. A morphometric analysis of the labial salivary glands of healthy young adults. In: Collan Y, Romppanen T, eds. Morphometry in morphological diagnosis. Kuopio: Kuopio University Press, 1982:169-73.

${ }^{27}$ Hené RJ, Van Den Hul H, Kater L. Sicca syndrome: diagnosis and differential diagnosis. Proceedings of the Fifth European Conference of International Medicine 1979:73-7.

${ }^{28}$ Eisenbud L, Platt N, Stern M, D'Angelo W, Summer PH. Palatal biopsy as a diagnostic aid in the study of connective tissue diseases. Oral Surg 1973;35:642-8.

${ }^{29}$ Mach PS, Amor B, Messing P, Chicault R, Ghozlan R, Delbarre F. Salivary immunoglobulin determinations: their diagnostic value in Sjögren's syndrome. Biomedicine 1976;25:31-5.

${ }^{30}$ Moutsopoulos H, Chused T, Mann D, et al. Sjögren's syndrome (sicca syndrome): current issues. Ann Intern Med 1980;92:212-26.

${ }^{31}$ Fischbach M, Char M, Christensen M, et al. Immune complexes in Sjögren's syndrome. Arthritis Rheum 1980;23:791-5.

${ }^{32}$ Fox RI, Carstens SA, Fong S, Robinson CA, Howell F, Vaughan JH. Use of monoclonal antibodies to analyze peripheral blood and salivary gland lymphocyte subsets in Sjögren's syndrome. Arthritis Rheum 1982;25:419-26.

${ }^{33}$ Shillitoe EJ, Daniels TE, Whitcher JP, Vibeke Strand C, Talal N, Greenspan JS. Antibody to cytomegalovirus in patients with Sjögren's syndrome, as determined by an enzyme linked immunosorbent assay. Arthritis Rheum 1982;25:260-5.

Requests for reprints to: Dr PCM de Wilde, Department of Oral Pathology, University of Utrecht, Sorbonnelaan 16, 3584 CA Utrecht, The Netherlands. 